\title{
Genotoxicity of multi-walled carbon nanotubes at occupationally relevant doses
}

\author{
Katelyn J Siegrist ${ }^{1}$, Steven H Reynolds ${ }^{1}$, Michael L Kashon ${ }^{1}$, David T Lowry ${ }^{1}$, Chenbo Dong ${ }^{2}$, Ann F Hubbs ${ }^{1}$, \\ Shih-Houng Young ${ }^{1}$, Jeffrey L Salisbury ${ }^{3}$, Dale W Porter', Stanley A Benkovic ${ }^{1}$, Michael McCawley ${ }^{4}$, \\ Michael J Keane', John T Mastovich ${ }^{5}$, Kristin L Bunker ${ }^{5}$, Lorenzo G Cena ${ }^{1}$, Mark C Sparrow ${ }^{5}$, Jacqueline L Sturgeon ${ }^{5}$, \\ Cerasela Zoica Dinu ${ }^{2^{*}}$ and Linda M Sargent ${ }^{* *}$
}

\begin{abstract}
Carbon nanotubes are commercially-important products of nanotechnology; however, their low density and small size makes carbon nanotube respiratory exposures likely during their production or processing. We have previously shown mitotic spindle aberrations in cultured primary and immortalized human airway epithelial cells exposed to single-walled carbon nanotubes (SWCNT). In this study, we examined whether multi-walled carbon nanotubes (MWCNT) cause mitotic spindle damage in cultured cells at doses equivalent to 34 years of exposure at the NIOSH Recommended Exposure Limit (REL). MWCNT induced a dose responsive increase in disrupted centrosomes, abnormal mitotic spindles and aneuploid chromosome number 24 hours after exposure to 0.024, 0.24, 2.4 and $24 \mathrm{\mu g} / \mathrm{cm}^{2}$ MWCNT. Monopolar mitotic spindles comprised 95\% of disrupted mitoses. Three-dimensional reconstructions of $0.1 \mu \mathrm{m}$ optical sections showed carbon nanotubes integrated with microtubules, DNA and within the centrosome structure. Cell cycle analysis demonstrated a greater number of cells in S-phase and fewer cells in the G2 phase in MWCNT-treated compared to diluent control, indicating a G1/S block in the cell cycle. The monopolar phenotype of the disrupted mitotic spindles and the G1/S block in the cell cycle is in sharp contrast to the multi-polar spindle and G2 block in the cell cycle previously observed following exposure to SWCNT. One month following exposure to MWCNT there was a dramatic increase in both size and number of colonies compared to diluent control cultures, indicating a potential to pass the genetic damage to daughter cells. Our results demonstrate significant disruption of the mitotic spindle by MWCNT at occupationally relevant exposure levels.
\end{abstract}

\section{Introduction}

Carbon nanotubes (CNT) are used in many consumer and industrial products including electronic devices, protective clothing, sports equipment and medical devices as well as vehicles for drug delivery [1-3]. Due to the wide variety of applications, the nanotechnology industry is predicted to grow to one trillion dollars by 2015 [4]. The low density and small size of carbon nanotubes make respiratory exposure likely during production and processing. Indeed, recent investigations have shown that carbon nanotubes can be aerosolized under

\footnotetext{
*Correspondence: cerasela-zoica.dinu@mail.wvu.edu; las1@cdc.gov ${ }^{2}$ Department of Chemical Engineering, Benjamin M. Statler College of Engineering and Mineral Resources, West Virginia University, Morgantown, WV 26505, USA

'National Institute for Occupational Safety and Health, Morgantown, WW 26505, USA

Full list of author information is available at the end of the article
}

workplace conditions [5-8]. Although carbon nanotubes have a large variety of applications, their potential health effects have not been fully investigated.

The low density, fiber-like geometry and durability of carbon nanotubes are characteristics shared with asbestos $[9,10]$. Single-walled and multi-walled carbon nanotubes have been shown to enter cells and induce DNA damage, sister chromatid exchange, chromosome damage and micronuclei in vitro in human keratinocytes, human breast cancer cell lines, human lung cancer epithelial cells and immortalized mouse fibroblasts (Balb/ 3 T3 cells) [11-15]. Micronuclear formation can result from either a high level of chromosome damage or mitotic spindle disruption. Research by Di Giorgio et al., 2011 demonstrated significant chromosome breakage by analysis of chromosome spreads as well as DNA damage by the comet assay in a mouse macrophage cell line

\section{Biomed Central}


24-48 hours after exposure to MWCNT (10-25 nm) and SWCNT (0.7-1.2 nm) material [16]. The carbon nanotube-exposed cells also had high levels of intracellular reactive oxygen species suggesting that carbon nanotubes can cause chromosome damage through reactive oxygen species [16]. Increased DNA damage due to oxygen radicals was also observed in imprinting control region mice (ICR) mice in vivo following intratracheal installation of 0.05 or $0.2 \mathrm{mg} \mathrm{MWCNT} / \mathrm{mouse}$ [11]. Carbon nanotubes bind to DNA at G-C rich regions in the chromosomes including telomeric DNA $[17,18]$. The interaction with the DNA results in a conformational change. DNA intercalation and telomeric binding can induce chromosome breakage suggesting that interaction of the nanotubes with the DNA may also be a source of chromosome damage. Recent investigations have shown that acid-washed single-walled carbon nanotubes of $1-4 \mathrm{~nm}$ in diameter and one micron in length induce centrosome fragmentation, multipolar mitotic spindles and errors in chromosome number in cultured immortalized and primary lung epithelial cells [19]. Furthermore, exposure of cancer cell lines to MWCNT of 5-10 nm diameter and one micron in length also results in multipolar mitotic spindles [20].

Mitotic spindle disruption and aneuploidy are a concern because these effects have been observed with the carcinogenic fiber, asbestos. In vitro investigations have demonstrated that chrysotile asbestos exposure causes multipolar mitotic spindles and a G2/M block similar to SWCNT and vanadium pentoxide exposure [19,21-24]. Asbestos exposure disrupts the mitotic spindle and causes aneuploidy through amplification of the centrosome $[21,22]$. By contrast, the mitotic disruption and aneuploidy resulting from vanadium pentoxide and SWCNT is associated with fragmented centrosomes [19,23]. Furthermore, in vitro examinations of asbestos and vanadium pentoxide potency have demonstrated that the disruption of the mitotic spindle and aneuploidy in cultured cells is strongly correlated with in vivo carcinogenesis [25-28]. Together these investigations indicate the importance of genotoxicity in carcinogenesis as well as validating the significance of culture models to predict carcinogenesis.

To simulate aerosol exposures in the workplace, rodents have been exposed to high aspect ratio particles by inhalation, pharyngeal aspiration or intratracheal installation. In a manner similar to asbestos, rodent pulmonary exposure to biopersistant carbon nanotubes has been shown to result in lung inflammation, epithelial cell proliferation, cellular atypia and mutations in the K-ras gene [29-32]. The lung is the principal site of carbon nanotube deposition and toxicity following aspiration or inhalation [31,33]. In vivo investigations have demonstrated that carbon nanotube exposure can cause macrophages without nuclei as well as dividing macrophages connected by nanotubes [30,31]. Exposure of rats to the MWCNT by pharyngeal aspiration has been shown to result in micronuclei formation in Type II epithelial cells further indicating the potential for genetic damage [13]. Inflammation, cellular proliferation, cellular atypia, mitotic spindle disruption, centrosome fragmentation and errors in chromosome number are linked with the development of cancer [34-40]. Chronic exposures to asbestos particles which induce strong inflammatory, proliferative and genotoxic responses in the lung are associated with an increased incidence of lung cancer in rodents [41,42]. Although the lung is the key target organ for particle toxicity, high aspect ratio carbon nanotubes have been shown to translocate to the subpleural space indicating that the mesothelial cells are also a potential target $[43,44]$.

The overall objective of our study was to examine the role of $\mathrm{CNT}$ diameter in the nanotube-induced genetic damage using carbon nanotubes prepared with the same acid washing procedure and one micron length used in our previous studies to evaluate the potential genotoxicity of the narrower SWCNT [24,45]. Because vanadium pentoxide has been demonstrated to induce aneuploidy and mitotic spindle disruption through fragmentation of the centrosome, we selected vanadium as the positive control for genotoxicity. Immortalized and primary lung epithelial cells were examined for the potential of MWCNTs to cause aneuploidy, mitotic spindle disruption, centrosome fragmentation, and cell cycle distribution following exposure of primary and immortalized human epithelial cells to occupationally relevant doses of 10-20 nm diameter MWCNT. Primary cells were used in the assays since the normal karyotype made it possible to determine changes in chromosome number after exposure. The concentrations chosen for the current investigation were selected to be relevant to previous in vivo exposure doses of MWCNT of 10-40 $\mu \mathrm{g}$ /mouse (0.5 $\mu \mathrm{g}$, $1 \mu \mathrm{g}$, and $2 \mu \mathrm{g} / \mathrm{kg}$ respectively) reported by Porter et al. [30]. In brief, the mouse lung burdens per alveolar epithelial surface area of $500 \mathrm{~cm}^{2} /$ mouse lung [46] correspond to in vitro concentrations of $0.02-0.08 \mu \mathrm{g} / \mathrm{cm}^{2}$. The minimal in vitro dose of $0.02 \mu \mathrm{g} / \mathrm{cm}^{2}$ MWCNT would require 4 weeks of exposure at the Occupational Safety and Health Administration (OSHA) permissible exposure limit for particles with an aerodynamic diameter of 5 microns or less of $5 \mathrm{mg} / \mathrm{m}^{3}[47,48]$. NIOSH has recently reduced the REL from $7 \mu \mathrm{g} / \mathrm{m}^{3}$ to $1 \mu \mathrm{g} / \mathrm{m}^{3}$ [49]. Although exposure to concentrations of carbon nanotubes equivalent to the current NIOSH REL of $1 \mu \mathrm{g} / \mathrm{m}^{3}$ would require 34 years to yield a equivalent exposure of the $0.024 \mu \mathrm{g} / \mathrm{cm}^{2}$, levels of MWCNT between 0.7 and $331 \mu \mathrm{g} / \mathrm{m}^{3}$ have been measured in workplace air $[6,7,50-52]$. 

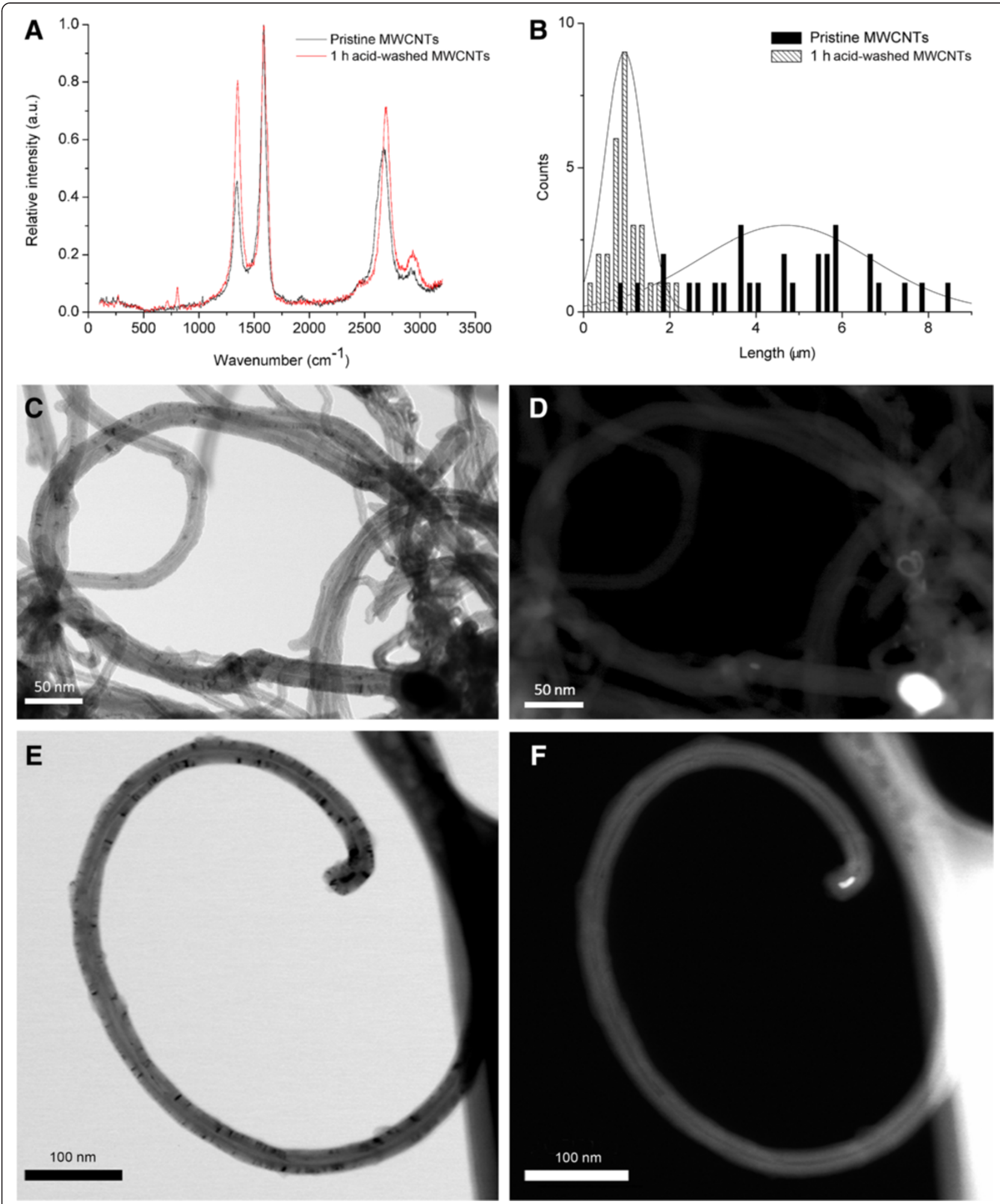

Figure 1 (See legend on next page.) 
(See figure on previous page.)

Figure 1 Raman characterization, electron microscopy analysis and length distribution of MWCNTs. Figure 1 A. The figure is a histogram of the Raman spectra of pristine (black) and one hour acid-washed carbon nanotubes (red). Four independent bands have been identified for both samples, i.e., $\mathbf{D}$ band around $1350 \mathrm{~cm}-1$, G band at $1585 \mathrm{~cm}-1$, G' band around $2690 \mathrm{~cm}-1$, and an additional band around $2930 \mathrm{~cm}-1$. Shifts in these bands are noticed for samples that have been treated with acid for $1 \mathrm{~h}$. Figure 1B. Histograms of length distribution of pristine (a) and 1 h acid-washed MWCNTs (b) as identified by tapping mode Atomic force microscopy (AFM). At least 30 nanotubes have been analyzed for each one of the samples. Figure 1C, D, E, F: Figure 1C shows a representative bright-field image and Figure 1D shows the corresponding dark-field image of the MWCNT sample. The images demonstrated that the MWCNTs have a diameter of 10-20 nm and a typical multi-walled tubular morphology. Figure 1D shows representative dark-field STEM (DF-STEM) image of the native MWCNT sample that was acquired. The analysis demonstrated low amounts of the iron catalyst. Figure $1 \mathbf{E}$ shows a representative bright-field image and Figure $1 \mathbf{F}$ shows the corresponding dark-field image of the MWCNT sample. The dark-field image provides atomic number contrast information. The bright $10 \mathrm{~nm}$ particle at the end of the MWCNT in Figure $1 \mathbf{F}$ is a catalyst particle. Energy dispersive X-ray spectroscopy (EDS) showed that the catalyst particle was iron-rich. Further analysis of the MWCNT sample identified low amounts of the iron catalyst.

\section{Results}

\section{Characterization of carbon nanotubes}

Raman spectroscopy was used to characterize the structure of pristine and acid-washed MWCNTs and to determine the degree of MWCNTs functionalization after acid treatment. Figure 1A shows the Raman spectra of pristine and acid-washed MWCNT. There are 4 bands identified in both pristine and acid-washed MWCNTs samples, i.e. D band around $1350 \mathrm{~cm}^{-1}$ that reflects the level of disorder in the sample, the $G$ band around $1585 \mathrm{~cm}^{-1}$ indicative of the high degree order and wellstructured samples, the $G^{\prime}$ band around $2690 \mathrm{~cm}^{-1}$ representing the binary disordered band and lastly the peak around $2930 \mathrm{~cm}^{-1}$ indicative of the oxidation level of the sample being characterized. As shown, the D band was wider and had a higher frequency for the acid-washed sample when compared to the pristine MWCNTs. The shift in the D band indicates that the acid treatment minimally altered the chemical structure of MWCNTs by disrupting the structured walls and introducing additional functional groups (carboxylic acid groups) [53]. For the acid-washed MWCNTs there was also a shift of G' band towards higher frequency; this may be due to the removal of metal catalysts, increase in the number of functional groups having electron accepting ability and decrease in the amorphous carbon. The ratio of intensity of $D$ to $G$ peaks indicate the degree of functionalization [54-56] and was 0.59 for pristine and 0.81 for $1 \mathrm{hr}$. acid-washed MWCNTs. This also confirms that the acid treatment increased the number of functional groups (i.e. free carboxylic acid groups) on the walls of the MWCNTs samples. Energy dispersive X-ray spectroscopy (EDX) confirmed the increase in the oxygen content due to the acid treatment and thus the increase in the MWCNTs degree of functionalization with free carboxylic acid groups as shown in Additional file 1. Further, the acid washing also reduced the catalyst content in the sample (Fe, 0.81). The content of the iron, cobalt and nickel were further analyzed by inductively coupled plasma-mass spectrometry (ICP-MS). Specifically, the MWCNT by ICP-MS contained $0.03 \%$ Fe $\pm 0.001,0 \%$ cobalt, and $0 \%$ Nickel [57].
The length distribution of pristine and $1 \mathrm{~h}$ acid-washed MWCNT respectively is shown in Figure 1B (at least 30 individual MWCNTs were measured for each sample). AFM analysis showed that pristine MWCNT samples had an average length of $5499 \pm 3009 \mathrm{~nm}$ while $1 \mathrm{~h}$ acid-washed MWCNTs had an average length of $825 \pm 585 \mathrm{~nm}$ respectively indicating that acid treatment led to shortening of the nanotubes. The pristine and acid washed MWCNT had a diameter of $15 \pm 5 \mathrm{~nm}$. Moreover, acid washing also increased nanotube solubility in DMEM + FBS by two-fold compared to pristine MWCNT [58] as a result of the addition of the free carboxylic acid groups [2].

\section{Mitotic spindle disruption}

Two human epithelial cell populations were examined to determine whether MWCNT induced genetic damage. Immortalized respiratory epithelial cells (BEAS-2B) were used to determine the effects of MWCNT on the mitotic spindle. Primary respiratory epithelial cells (SAEC) were included in the analysis to determine whether MWCNT induced errors in chromosome number. Treatment with acid-washed MWCNT induced a dose dependent mitotic spindle disruption (Figure 2A). The disrupted mitotic spindles were predominantly monopolar (Figure $2 \mathrm{~B}$ ). Figure $2 \mathrm{C}$ shows a 20x photomicrograph of the cultured cells with three monopolar mitotic spindles in one $40 \times$ field. Only $5-10 \%$ of the disrupted mitotic spindles were multipolar (Figure 2D).

\section{Chromosome number}

Primary SAEC cells from a normal donor were used to investigate the effects of MWCNT on the chromosome number. The normal karyotype of the primary cells made it possible to evaluate the treatment related changes in chromosome number. FISH analysis for either chromosome 1 or 4 demonstrated a $2.25 \pm 1.0 \%$ aneuploidy in the untreated SAEC cells (Table 1). The frequency of the cells with abnormal chromosome number is within the range reported in adult human cells in culture $[59,60]$. By contrast, the MWCNT-treated SAEC cells had a level of aneuploidy that was comparable to the vanadium pentoxide-treated 


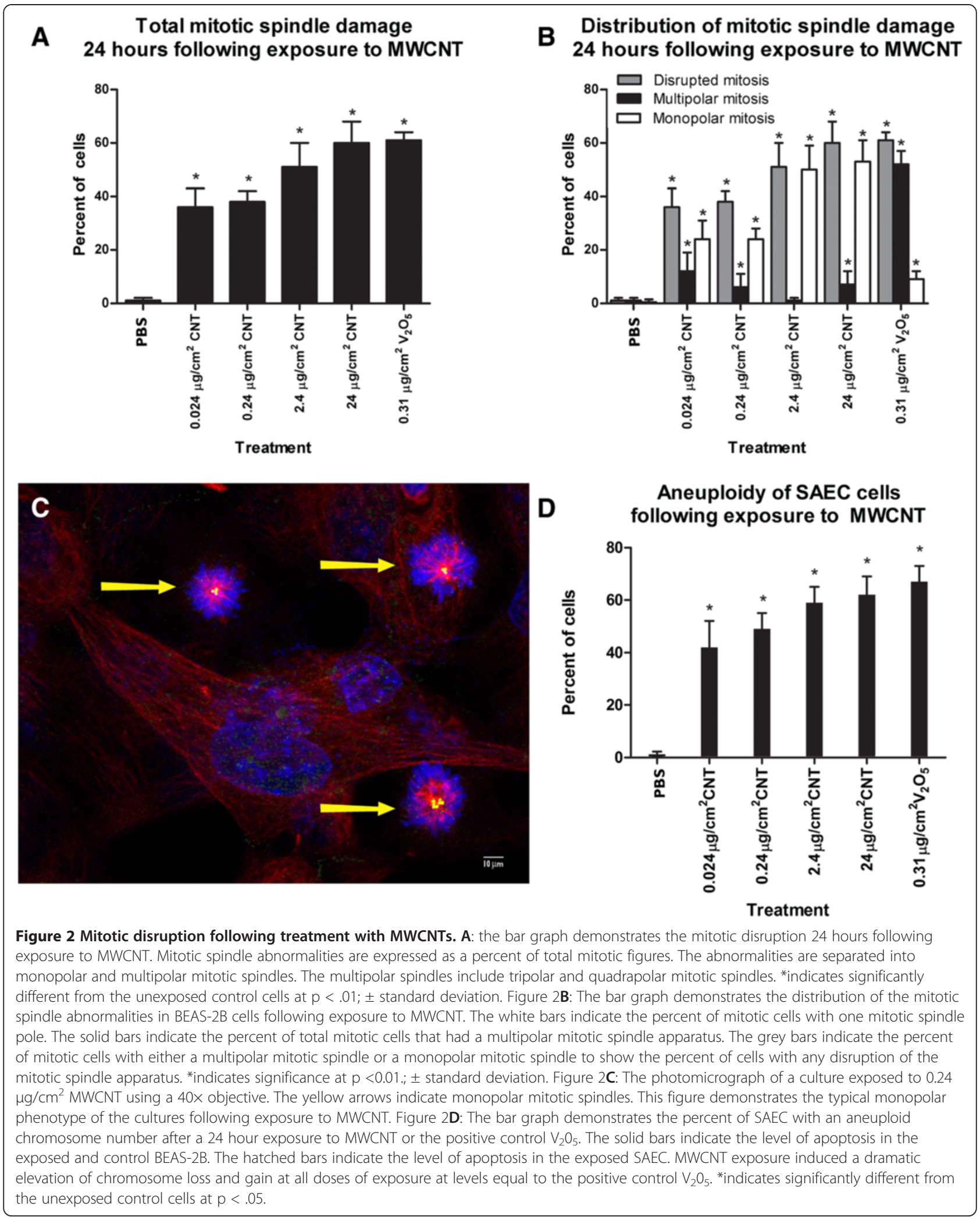


Table 1 Percent of chromosome errors in SAEC cells following treatment with MWCNT orV $\mathbf{2}_{5}$

\begin{tabular}{|c|c|c|c|c|c|c|}
\hline Dose MWCNT $\mu \mathrm{g} / \mathrm{cm}^{2}$ & $\begin{array}{l}\text { Total } \% \text { aneuploid } \\
\text { cells }\end{array}$ & $\begin{array}{l}\text { \% loss of } \\
\text { chromosome } 1\end{array}$ & $\begin{array}{l}\text { \% gain of } \\
\text { chromosome } 1\end{array}$ & $\begin{array}{l}\text { \% loss of } \\
\text { chromosome } 4\end{array}$ & $\begin{array}{l}\text { \% gain of } \\
\text { chromosome } 4\end{array}$ & $\begin{array}{l}\% \text { gain of both } \\
\text { chromosomes }\end{array}$ \\
\hline Diluent & $2.25 \pm 1.0$ & $1.0 \pm 1.0 \%$ & $1.0 \pm 1.0 \%$ & $1.25 \pm 1.0 \%$ & $1.0 \pm 1.0 \%$ & 0 \\
\hline 0.024 & $42 \pm 10^{*}$ & $2.0 \pm 1.26$ & $15.0 \pm 2.0^{*}$ & $3.0 \pm 1.26^{*}$ & $16.4 \pm 2.0^{*}$ & $12.0 \pm 3.0^{*}$ \\
\hline 0.24 & $49 \pm 6.0$ & $1.7 \pm 0.7^{*}$ & $23.7 \pm 5.0^{*}$ & $2.0 \pm 10^{*}$ & $25 \pm 4.0^{*}$ & $18 \pm 6.0^{*}$ \\
\hline 2.4 & $59.0 \pm 6.0^{*}$ & $3.4 \pm 0.8^{*}$ & $26.0 \pm 3.0^{*}$ & $4.3 \pm 1.2^{*}$ & $25 \pm 10^{*}$ & $23 \pm 5.0^{*}$ \\
\hline 24 & $62 \pm 7.0^{*}$ & $7 \pm 3.0 \% *$ & $49.3 \pm 4.0 \% *$ & $8.0 \pm 3.0 \% *$ & $53.3 \pm 5 \%^{*}$ & $44 \pm 5.0 \% *$ \\
\hline \multicolumn{7}{|l|}{ Dose vanadium $\mu \mathrm{g} / \mathrm{cm}^{2}$} \\
\hline 0.31 & $69.0 \pm 7.0^{*}$ & $23.0 \pm 5.0^{*}$ & $35.0 \pm 9.0^{*}$ & $25.0 \pm 11^{*}$ & $34.0 \pm 7^{*}$ & $19.0 \pm 6^{*}$ \\
\hline
\end{tabular}

*Statistically significant at $p<.05$

The distribution of the aneuploidy that was contributed by chromosome 1 and by chromosome 4 is detailed in the table as "Total \% aneuploid cells". The percent of cells with a gain in chromosome 1 and/or of chromosome 4 are indicated in the table under "Gain" of each chromosome. Cells with both chromosomes gained are indicated by "Gain of both chromosomes". Cells with a loss of chromosome 1 and/or chromosome 4 are indicated in the table under "Loss" of each chromosome. *: $\mathrm{p}<0.05$ of the treated cells compared to diluent control exposed cultures; \pm standard deviation.

positive control cells (Figure 2D; Table 1). Abnormal chromosome number was significantly elevated following MWCNT treatment as follows: $62 \pm 7.0 \%, 24 \mu \mathrm{g} /$ $\mathrm{cm}^{2} ; 59.0 \pm 6.0 \%, 2.4 \mu \mathrm{g} / \mathrm{cm}^{2} ; 49 \pm 6.0 \%, 0.24 \mu \mathrm{g} / \mathrm{cm}^{2}$ and $42 \pm 10 \%, 0.024 \mu \mathrm{g} / \mathrm{cm}^{2}$ compared with control incidence of $2.25 \pm 1.0 \%$. Treatment with $0.31 \mu \mathrm{g} /$ $\mathrm{cm}^{2} \mathrm{~V}_{2} \mathrm{O}_{5}$ resulted in $67 \pm 6.0 \%$ aneuploid cells. The chromosome alterations in the MWCNT treated cells were predominantly gains of either chromosome 1 or 4 (Table 1). The chromosome losses accounted for $24 \%$, $24 \mu \mathrm{g} / \mathrm{cm}^{2} ; 13 \%, 2.4 \mu \mathrm{g} / \mathrm{cm}^{2} ; 8 \%, 0.24 \mu \mathrm{g} / \mathrm{cm}^{2}$ and $12 \%$, $0.024 \mu \mathrm{g} / \mathrm{cm}^{2}$. Chromosomal gains accounted for over $70 \%$ of the aneuploidy (Table 1 ). There was also a dose-dependent increase in the number of cells with gains of both chromosomes 1 and 4 indicating an increase in polyploid cells. The number of alterations of chromosome 1 was not statistically different than the alterations of chromosome 4, therefore; there was not a bias for a change of either chromosome.

\section{Interaction of carbon nanotubes with mitotic spindle apparatus}

The MWCNTs were 10-20 nanometers in width. Nanotubes of 10 nanometers or greater can be observed using differential interference contrast imaging. MWCNTs were observed in the cytoplasm and the nucleus (Figure 3A). The MWCNTs also had a strong association with the centrosomes as shown in Figure 3B. The high
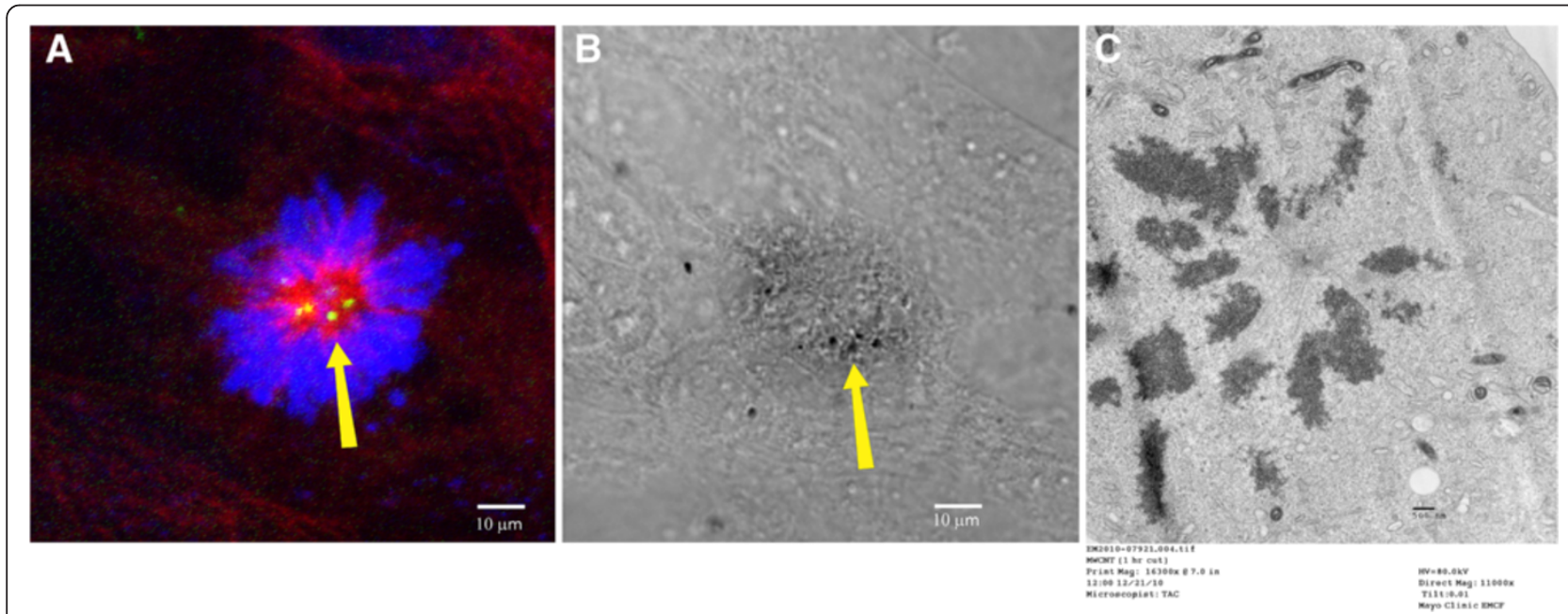

Figure 3 MWCNT-treated cell with one spindle pole. The photographs in Figure $3 \mathbf{A}-\mathbf{C}$ show a monopolar mitotic spindle with one pole rather than the two poles which would be expected in a normal cell. The details of the detection protocol for the mitotic spindle components and the photography using the Zeiss Confocal are in the methods section. The tubulin in $3 \mathbf{A}$ was stained red using Spectrum red and indirect immunofluorescence. The DNA was detected by DAPI and was blue. The nanotubes were imaged using differential interference contrast and are black. In Figure 3B, the nanotubes can be seen in the nucleus, in association with microtubules, the DNA and the centrosome. Serial optical sections at 0.1 micron intervals using confocal microscopy confirmed the location of the nanotubes in the nuclear DNA and the tubulin including the microtubules of the mitotic spindle. Figure $3 \mathbf{C}$ is a high resolution TEM of a monopolar mitosis. The image was photographed at 11000x magnification. 
frequency of monopolar mitotic spindles allowed confirmation of the monopolar phenotype by transmission electron microscopy (TEM) as shown in Figure 3C. The $3 \mathrm{D}$ reconstructed image demonstrates strong physical associations between the carbon nanotubes, the microtubules and DNA and the centrosomes (Figure 4A- B). The $3 \mathrm{D}$ reconstruction further demonstrated that MWCNTs not only associated with the centrosome but inside the centrosomal structure (Figure 4C).

\section{Viability and clonal growth}

Exposure to MWCNT did not reduce viability 24 hours after treatment in either the primary SAEC or the immortalized BEAS-2B cells (Figure 5A). Vanadium pentoxide treatment resulted in reduced viability in both SAEC and the BEAS-2B cells. Seventy-two hours following exposure, the viability of the SAEC cells was significantly reduced in cells exposed to $0.024,0.24,2.4$ or $24 \mu \mathrm{g} / \mathrm{cm}^{2}$ MWCNT (Figure 5B). Three weeks following exposure, the BEAS-2B cells had a small increase in colony formation at $0.024 \mu \mathrm{g} / \mathrm{cm}^{2}$ (Figure $5 \mathrm{C}$ ). One month following exposure, the SAEC cells had a reduced number of colonies at the highest dose; however, exposure to 0.024, 0.24 and $2.4 \mu \mathrm{g} / \mathrm{cm}^{2}$ resulted in a dramatic increase in colony formation (Figure 5C).

\section{Cell cycle}

The impact of MWCNT-treatment on the cell cycle was evaluated by Click-iT EdU Flow Cytometry assay. Treatment with $24 \mathrm{ug} / \mathrm{cm}^{2}$ MWCNT induced a statistically significant increase in the percent of cells in $\mathrm{S}$ phase from $32.11 \%$ (PBS-treated) to $40.1 \%$ (Table 2). When the cells in G2 phase of the cell cycle were compared, exposure to the positive control, arsenic, resulted in $32.1 \%$ of the cells in G2 compared to $18.30 \%$ of the cells in the PBS control group thus indicating an arsenic-induced block in G2 (Table 2, $\mathrm{p}<.05$ ).

\section{Discussion}

Since their discovery in 1991 [61] carbon nanotubes have been used for a variety of applications including fiber optics [62], conductive plastics, molecular electronics as well as biological and biomedical applications [63]. Although the durability and fiber-like structure of carbon nanotubes have raised concerns that carbon nanotubes may have effects similar to asbestos, the health effects have not been fully investigated $[64,65]$. Our data reported here are the first to show induction of monopolar mitotic spindles, aneuploidy, and a G1/S block in the cell cycle as well as a dramatic increase in colony formation following exposure to $10-20 \mathrm{~nm}$ diameter MWCNT. Exposure to $0.024 \mu \mathrm{g} \mathrm{MWCNT} / \mathrm{cm}^{2}$ resulted in errors in chromosome number and mitotic spindle aberrations in greater than $40 \%$ of the cells examined.
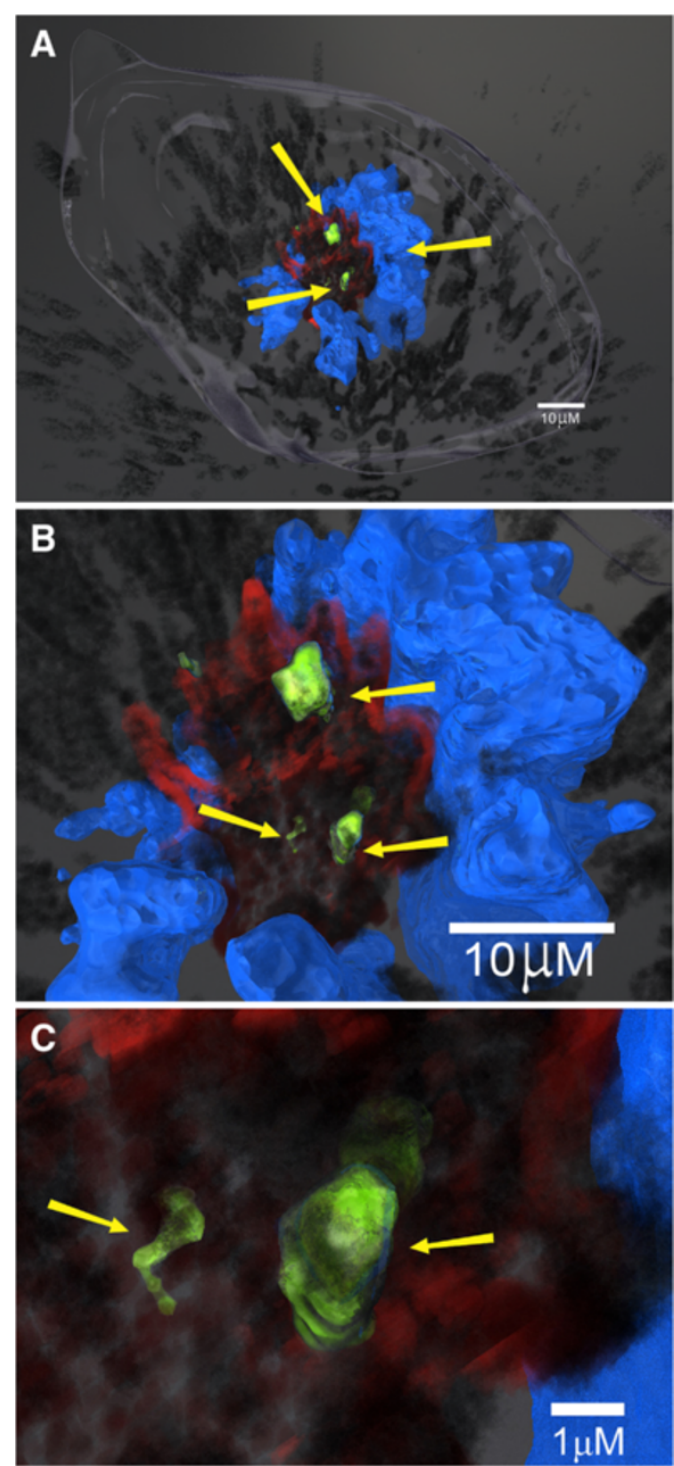

Figure $4 \mathrm{~A}, \mathrm{~B}$ and C: Three-dimensional reconstruction of a MWCNT-treated mitotic cell. Figure $4 \mathbf{A}$ : This 3-dimension reconstruction was created from serial optical laser scanning confocal microscopy sections using immunofluorescence to identify centrosomes and microtubules while differential interference contrast was used to visualize aggregated MWCNT as previously described [24]. Briefly, nanotubes of 10 nanometers or greater could be visualized by their interference with transmitted light using DIC imaging. Because the nanotubes block the light, the nanotubes produce a black image. The reconstructed image shows aggregated nanotubes which appear as irregular tangled black structures located inside the cell in association with the centrosomes (green), the microtubules (red) and the DNA (blue). In this cell, the one spindle pole, the doughnut shaped DNA arrangement and the disruption of microtubule attachments to clustered centrosome fragments into a monopolar spindle apparatus suggest major perturbations in cell division. The yellow arrows indicate nanotubes in association with mitotic spindle and the DNA. Figure 4B The yellow arrows indicate the nanotubes (black) in association with the centrosomes (green) and the microtubules (red). Figure 4C: The yellow arrows indicate nanotubes (black) inside the centrosome structure (green). 
A Viability of respiratory epithelial cells 24 hours following exposure to MWCNT

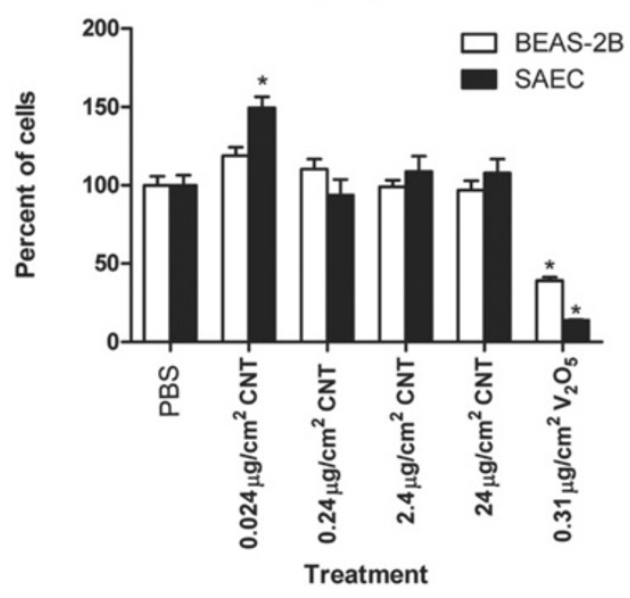

B Viability of respiratory epithelial cells 72 hours following exposure to MWCNT

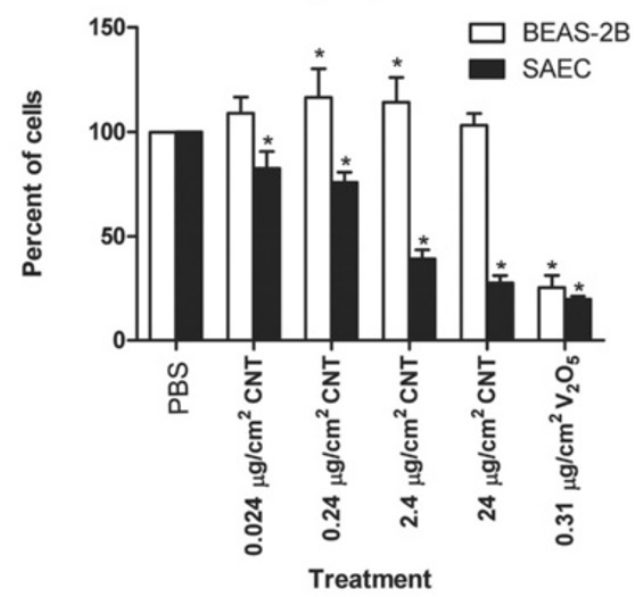

C Clonal growth of respiratory epithelial cells exposed to MWCNT for 24 hours

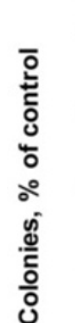

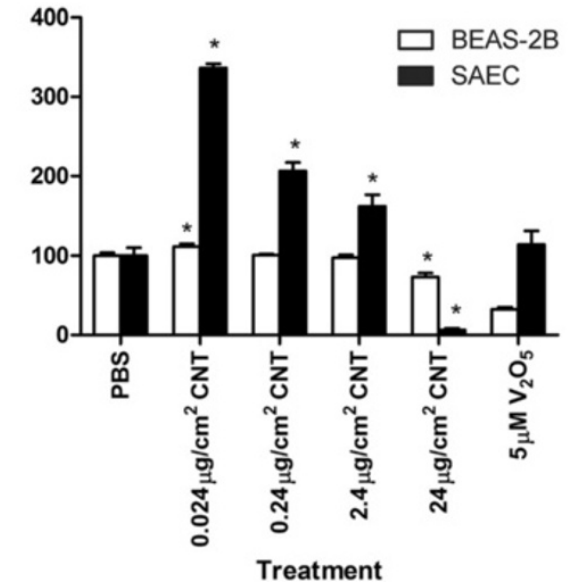

Figure 5 A, B and C: Clonal growth and viability of BEAS-2B and SAEC cells. Figure $5 \mathbf{A}$ : The bar graph represents viability of BEAS-2B and SAEC cells 24 hours following exposure to MWCNT or $V_{2} \mathrm{O}_{5}$. The white bar indicates viability of BEAS-2B cells. The black bar indicates viability of SAEC cells. The viability was not reduced in either the BEAS-2B or the SAEC cells. Figure 5B: The bar graph represents the viability of BEAS- $2 B$ and SAEC cells 72 hours following exposure to MWCNT. The white bar indicates the viability of BEAS-2B cells and the black bar indicates viability of SAEC cells. MWCNT exposure resulted in reduced viability in the SAEC and the BEAS-2B at $0.024,0.24,2.4$ and $24 \mathrm{\mu g} / \mathrm{cm}^{2}$ compared to control cells. The exposure to $\mathrm{V}_{2} \mathrm{O}_{5}$ resulted in reduced viability in SAEC treated cells at all doses. ${ }^{*}$ indicates statistical significance of the treated cells compared to control cells at $p<0.05$. Figure $5 \mathrm{C}$ : The bar graph demonstrates the clonal growth in BEAS-2B cells 3 weeks following MWCNT exposure and SAEC cells 4 weeks following exposure. The black bars indicate the mean number of colonies of BEAS-2B cells and the white bars indicate mean number of colonies in SAEC cells. *indicates significance at $p<0.05$ of treated cells compared to control cultures.

The dramatic increase in MWCNT-induced colony formation and aneuploidy observed in the primary SAEC cells was significantly higher than was previously observed in SWCNT-treated cells. The proliferation of cells with a high degree of genetic damage could result in the expansion of a population of genetically-altered cells. Cell proliferation is important in the second stage of pulmonary carcinogenesis, tumor promotion, while genetic instability is observed during the progression of preneoplastic cells to frank neoplasia [40,66]. During the progression of neoplastic disease, centrosome disruption is observed. The degree of centrosome disruption and aneuploidy is important because it is correlated with tumor stage [67-69].

The level of centrosome fragmentation, mitotic spindle damage and aneuploidy following MWCNT exposure was similar to the effects of the known carcinogen and positive control, vanadium pentoxide. MWCNTs were found in association with the DNA, the microtubules, the centrosomes as well as inside the centrosome structure. A previous investigation has shown that MWCNT are incorporated into the microtubules during polymerization thus forming a microtubule/nanotube hybrid [70]. The mitotic disruption that was observed following exposure to MWCNT may be due to a number of factors including incorporation of the nanotubes into the centrosome and microtubules of the mitotic spindle resulting in failed cytokinesis, failed centrosome duplication or inhibited centrosome separation. If two spindle poles are not formed during cell division, the chromosomes are not divided equally and chromosome errors occur.

Exposures that induce monopolar mitotic spindles produce daughter cells that fail to undergo cytokinesis and have double the number of chromosomes (polyploid) [71-73]. Although the data from the current investigation 
Table 2 Distribution of the cell cycle in BEAS-2B cells 24 hours after treatment

\begin{tabular}{llll}
\hline Treatment & \% G1 & \% S & \% G2 \\
\hline 24 hour PBS & $43.25 \pm 5.6$ & $32.11 \pm 6.5$ & $18.30 \pm 5.3$ \\
24 hour As & $35.6 \pm 6.9$ & $26.38 \pm 7.9$ & $32.10 \pm 6.7^{*}$ \\
24 hour MWCNT & $39.8 \pm 4.0$ & $40.1 \pm 5.6^{*}$ & $15.90 \pm 3.3$
\end{tabular}

The table demonstrates the mean of percent of cells in $\mathrm{G} 1, \mathrm{~S}$ and $\mathrm{G} 2$ phase of the cell division 24 hours following treatment with media, $5 \mu \mathrm{M}$ arsenic or to $24 \mathrm{\mu g} / \mathrm{cm}^{2}$ MWCNT. The data is based on replicates of 6 that were repeated in 9 independent experiments.

*: $\mathrm{p}<0.05$ of the treated cells compared to diluent control exposed cultures.

demonstrated that the aneuploidy was predominantly due to a gain of chromosomal material or polyploidy, the chromosomes were also lost in a significant number of cells suggesting that the genetic damage was due to more than a failure of cytokinesis. Asakura et al. [74] observed polyploid cells in cancer cell lines following exposure to 0.25 to $50 \mu \mathrm{g}$ MWCNT of $80 \mathrm{~nm}$ diameter [74]. Although detailed analysis of chromosome loss and gain was not possible in a cancer cell line, the study demonstrated a significant number of polyploid cells which they attributed to a failure of cytokinesis. Carbon nanotubes have been observed in the bridge separating dividing cells [75]. Three dimensional reconstruction of MWCNT-exposed cells in the current study and of previously published SWCNTexposed mitotic figures have shown carbon nanotubes integrated with the microtubules, the DNA and within the centrosome structure $[19,24]$. The disruption of cell division that has been observed following carbon nanotube exposure may be due to the incorporation of the carbon nanotubes into the microtubules that make up the division apparatus.

In this study, we observed fragmented centrosomes clustered into a single pole. These results are in sharp contrast to the multipolar mitotic spindles that have been observed with narrower SWCNT $[19,20]$.

Centrosomes are duplicated in early G1/S of the cell cycle. The separation of the mother and daughter centrosomes by proteolytic enzymes is necessary for the exit from $\mathrm{S}$ phase and the formation of a bipolar mitotic spindle [76]. Incorporation of the stiff MWCNT into the centrosome may have resulted in a more rigid centrosomal structure which fractured during mitosis. In addition, the integration of the nanotubes into the centrosome structure could have prevented the proteolysis of the linker connecting duplicated mother and daughter centrioles in G1/S thereby preventing the centrosome separation necessary for the formation of a bipolar spindle [76]. Furthermore the excess of cells in the $S$ phase and significantly lower number of cells in the G2 phase in the MWCNT-treated compared to the control cells in the current investigation indicate a G1/S block and a failure to progress to G2. Interaction of the nanotubes into the microtubules would potentially impact many cellular process including cellular transport of organelles (lysosomes, mitochondria, Golgi apparatus and endoplasmic reticulum), RNA and protein transport as well as phagocytosis and cell movement [77]. Kinesin and dynein motors move the organelles, chromosomes, proteins and RNA. Defects in the microtubule surface have been reported to result in detaching of the motors from the microtubule and interruption of cell signaling [77-80]. Aberrant cell signaling is a concern because it is important in the progression of carcinogenesis [81-83].

Although both SWCNT and MWCNT had a strong association with the microtubules that make up the mitotic spindle and induced aberrant mitotic spindles, the data suggests that the type of damage may be determined by the diameter of the carbon nanotubes. SWCNT of 1-2 nm in diameter [45], MWCNT of 5$10 \mathrm{~nm}$ [20] and the NanoLabs 10-20 nm MWCNT form hybrids with microtubules [70]. Both the SWCNT and the 10-20 nm MWCNT are incorporated into the centrosome structure. The stiffness of the nanotubes is determined by their diameter [84]. Although, carbon nanotubes have similar mechanical properties to the microtubules, the stiffness of the carbon nanotubes is a thousand-fold greater than that of the microtubules [84]. The incorporation of the more rigid MWCNT into the microtubules that make up the mitotic spindle fibers and the centrosome may reduce the elasticity of the mitotic spindle apparatus to a greater degree than the SWCNT. The elasticity of the mitotic apparatus is a critical factor in the separation of the centrosomes to organize two spindle poles as well as in the separation of the chromosomes during cell division [85].

Evidence from rodent exposure studies has demonstrated that high aspect ratio nanoparticles have carcinogenic properties $[9,64,86,87]$. Inhalation exposure is the route that most closely resembles occupational exposure. The lung is the principal target organ for carbon nanotube exposure [43]. The long thin carbon nanotubes induce inflammation, cell proliferation of type II epithelial cells and cellular atypia [30,31,33]. Recent investigations have shown that inhaled MWCNT migrate to the subpleural wall $[44,88]$. The fiber-like structure, evidence of carbon nanotube-induced inflammation, proliferation and cellular atypia in the lung as well as migration to the subpleural space, inflammation, macrophage injury and evidence of genotoxic damage have raised concerns that the material has carcinogenic properties similar to asbestos $[44,64,89]$. The lung as well as the parietal pleura is the sites of asbestos-induced carcinogenesis [64,90-93]. Injection of high doses of $100 \mathrm{~nm}$ diameter MWCNT into the abdominal cavity of p $53+/-$ mice has been shown to induce mesothelioma on the surface of the diaphragm [94]. In a more recent investigation of p53 +/- mouse exposure, Takagi et al. demonstrated a dose response of mesothelioma development after 
peritoneal injection of 3-300 micrograms of Mitsui-7 MWCNT [95]. Nagi et al. investigated the role of nanotube diameter in the development of mesothelioma in a rat model [96]. Greater inflammation and mesothelioma development were observed with the $50 \mathrm{~nm}$ diameter Mitsui-7 MWCNT of 10 microns or less in length compared to nanotubes of $145 \mathrm{~nm}$ diameter and similar length [96]. The mouse studies were criticized due to the route of exposure and the sensitivity of the genetically modified p53 knock-out mouse strain; however, the induction of mesothelioma was significant. The demonstration of mesothelioma at high exposures combined with our findings revealing disruption of the integrity of the division apparatus further suggest a carcinogenic potential for MWCNT. A manuscript in press by Sargent et al. has demonstrated that inhaled Mitsui-7 MWCNT material promoted the formation of lung adenocarcinomas in B6C3F1 hybrid mice following 3-methylcholanthrene (MCA) initiation [97]. While the data did not indicate tumor initiation by MWCNT, the exposure resulted in lung adenocarcinoma and adenoma in $90.5 \%$ of the mice exposed to MCA followed by inhaled MWCNT. The mouse lung tumors were large and $15 \%$ of the tumors were metastatic indicating tumor progression with some forms of MWCNT. Furthermore, the strong MWCNT-induced tumor promotion was observed in a hybrid mouse that is intermediate in sensitivity to lung cancer $[98,99]$. The exposure dose of the tumor promotion study of $32 \mu \mathrm{g} /$ mouse is only 2.6 fold higher than the dose of the current in vitro investigation that shows significant chromosomal and mitotic spindle effects at the lowest administered dose of $0.024 \mu \mathrm{g} / \mathrm{cm}^{2}$ [19]. Although lung cancer or mesothelioma have not been observed in humans exposed to MWCTs, centrosome disruption, aneuploidy and mitotic spindle aberrations as well as recent data indicating mesothelioma as well as lung tumor promotion and progression are a concern and indicate that caution should be used to prevent respiratory exposure to workers during the production or use of commercial products.

\section{Materials and methods}

\section{Multi-walled carbon nanotubes acid washing}

Multi-walled carbon nanotubes produced by chemical vapor deposition (Nanolab Inc. PD15L5-20) were acidwashed to remove iron catalyst. The MWCNT were suspended in a mixture of $3: 1 \mathrm{v} / \mathrm{v}$ sulfuric acid $\left(\mathrm{H}_{2} \mathrm{SO}_{4}\right)$ (96.4\%, Fisher Scientific, Pittsburgh, PA): nitric acid $\left(\mathrm{HNO}_{3}\right)$ (69.5\%, Fisher Scientific, Pittsburgh, PA) for 1 hour in a water bath sonicator (Branson 2510, Fisher, Pittsburgh, PA) over ice. The mixture was subsequently diluted in deionized water $(2 \mathrm{~L})$ and filtered through a $0.2 \mu \mathrm{m}$ polycarbonate membrane filter (Millipore, USA); the filtration step was repeated 6 times to remove catalysts or impurities. All cell exposure experiments were performed with one hour acid-washed MWCNT materials.

\section{Characterization of MWCNT}

Atomic force microscopy (AFM) was used to investigate the length of both pristine and acid-washed MWCNT. Commercial Si tips (Asylum Research, AC240TS, USA) were used at their original resonance frequency, varying from 50 to $90 \mathrm{kHz}$. Pristine or acid-washed nanotubes $(10 \mu \mathrm{g} / \mathrm{ml})$ were deposited on mica surfaces $(9.5 \mathrm{~mm}$ diameter, 0.15-0.21 thickness, Electron Microscopy Sciences, USA) and dried overnight under vacuum. Scans of $10 \mu \mathrm{m} \times 10 \mu \mathrm{m}$ were acquired using tapping mode in air. At least 30 individual MWCNTs were analyzed to determine their length.

Raman spectroscopy was used to characterize the structure of both pristine and acid-washed MWCNTs. Raman analyses were performed at room temperature using a Renishaw InVia Raman Spectrometer (CL532-100, $100 \mathrm{~mW}, \mathrm{USA})$. The excitation source used an argon ion $\left(\mathrm{Ar}^{+}\right)$laser operating at $514.5 \mathrm{~nm}$. MWCNT (pristine or acid-washed, $1 \mathrm{mg}$ ) were mounted on a clean glass slide (Fisher, Pittsburgh, PA) and a 20× microscope objective was used to focus the laser beam to a spot size of $<$ $0.01 \mathrm{~mm}^{2}$ and to collect the scattered light. Low energy laser of $<0.5 \mathrm{mV}$ and an exposure time of $10 \mathrm{sec}$ were used to prevent unexpected heating effects of the MWCNT samples being analyzed. Detailed scans ranging from 100 to $3200 \mathrm{~cm}^{-1}$ were acquired.

The elemental analysis of the pristine and acid-washed carbon nanotubes was examined by energy dispersive Xray spectroscopy (EDX). Both pristine and acid-washed MWCNT (1 mg/ml in water) were vacuum-dried on silica wafers. The experiments were performed using a Hitachi S-4700 Field Emission Scanning Electron Microscope (USA) and backscattered (BSE) electron detection in a single unit and operating at $20 \mathrm{kV}$.

ICP-MS) was performed to further analyze the chemical composition of the nanotubes as described previously. Carbon nanotubes were suspended in pure $\mathrm{H}_{2} \mathrm{O}$ $(18.2 \mathrm{M} \Omega-\mathrm{cm})$ at a concentration of $1.0 \mathrm{mg} / \mathrm{ml}$. One $\mathrm{ml}$ of each vortexed suspension was added to a $100 \mathrm{ml}$ polytetrafluoroethylene digestion tube (CEM, Matthews, $\mathrm{NC}$ ) along with $9.0 \mathrm{ml}$ of ultrapure $\mathrm{HNO}_{3}$ and $1.0 \mathrm{ml}$ of ultrapure $\mathrm{H}_{2} \mathrm{O}_{2}$ (Fisher Optima, Fisher Scientific, Pittsburgh, PA). Three replicate samples for each nanotube type were digested in the Microwave-Assisted Reaction System (CEM, Matthews, NC) by ramping up to $200^{\circ} \mathrm{C}$ for $15 \mathrm{~min}$., holding at $200^{\circ} \mathrm{C}$ for 30 minutes, then cooling to $22^{\circ} \mathrm{C}$, adapting a procedure as previously described [100]. There was no visible carbonaceous material remaining in any of the samples after digestion. After suspension $(1 \mathrm{mg} / \mathrm{ml})$, the metal content of the nanotubes was analyzed by ICP-MS using the Perkin-Elmer Nexion 300D 
[101], using ${ }^{54} \mathrm{Fe},{ }^{60} \mathrm{Ni}$, and ${ }^{59} \mathrm{Co}$ isotopes. Standards were certified multi-element standards in $1 \% \mathrm{HNO}_{3}$.

\section{Dispersity analysis}

The dispersity of pristine MWCNTs and acid-washed MWCNTs in Phosphate buffered Saline (PBS, Fisher, Pittsburgh, PA) was determined by centrifuging the corresponding suspensions (initial concentration $5 \mathrm{mg} / \mathrm{mL}$ for both pristine and acid-washed MWCNTs) at $3000 \mathrm{rpm}$ for $5 \mathrm{~min}$. Subsequently, $0.8 \mathrm{~mL}$ of the supernatant mixture was filtered through a $0.2 \mu \mathrm{m}$ filter membrane. After complete drying under vacuum, the amount of pristine MWCNTs or acid-washed MWCNTs on the filter membrane was measured and the dispersity was calculated based on the starting volumes. The obtained values do not reflect the saturation dispersity.

\section{Cell culture}

Two human respiratory epithelial cell populations were used to examine the potential genetic damage to MWCNT exposure. Immortalized human bronchial epithelial cells (BEAS-2B, ATCC, Manassas, VA) cultures of passage 4-6 were used to examine the mitotic spindle integrity. The high mitotic rate of the BEAS-2B cells allows examination of sufficient number of mitotic spindles following treatment. BEAS-2B cells grown in serum enriched media double every $18-20$ hours and have normal mitotic spindle morphology. The high mitotic index of the BEAS-2B cells made it possible to analyze a sufficient number of mitotic spindles during the 24 hour exposure. Primary small airway respiratory epithelial cells (SAEC; Lonza, Walkersville, MD) from a normal human donor were used to determine the response of a normal cell population. In addition, the normal karyotype of the primary cells was essential for the examination of aneuploidy. The SAEC cells double every 20-24 hours which allowed analysis of a potential change in chromosome number and centrosome morphology of cells that have divided during the 24 hour exposure. The low mitotic index of the SAEC cells $(0.5 \%)$ prevented the analysis of mitotic spindle integrity in this cell population. The BEAS-2B and SAEC cells were therefore analyzed 24 hours after exposure to allow a sufficient number of cells that have gone through division.

BEAS-2B cells were cultured in Dulbecco's Modified Eagle Medium (DMEM) media supplemented with 10\% serum (Invitrogen, Grand Island, NY). The SAEC cultures were cultured following manufacturer's directions and using Cabrex media (Lonza, Walkersville, MD). The cell cultures were examined by electron microscopy and cytokeratin 8 and 18 staining to verify the epithelial phenotype of the cells as described previously [102].

\section{Treatment protocol}

The immortalized BEAS-2B and the primary SAEC were exposed in parallel culture dishes to MWCNT or to the positive control, vanadium pentoxide (Sigma St. Louis, $\mathrm{MO})$. Three independent experiments were performed for each exposure for SAEC and BEAS-2B respectively. MWCNT and vanadium control were suspended in media and sonicated over ice for 5 minutes and $30 \mathrm{mi}$ nutes respectively. The cells were seeded in dishes and exposed $0,0.024,0.24,2.4$ and $24 \mu \mathrm{g} / \mathrm{cm}^{2}$ MWCNT or to $0.031 \mu \mathrm{g} / \mathrm{cm}^{2}$ vanadium pentoxide when the cells were $70 \%$ confluent. The one milliliter culture was treated with $0.024, .24,2.4$ and $24 \mu \mathrm{g} / \mathrm{ml}$ respectively. Twenty-four hours after exposure all cells were prepared for analysis of apoptosis and necrosis, integrity of the mitotic spindle, as well as the centrosome and chromosome number as described below.

\section{Viability and apoptosis}

Triplicate cultures were prepared in 96 well plates (Becton Dickinson Franklin Lakes, NJ) for the analysis of viability using the Alamar Blue bioassay (Invitrogen, Carlsbad, CA), following manufactures directions as described previously [24]. Eight wells were performed for each treatment and dose. Three independent experiments were performed for the analysis of cellular toxicity by Alamar Blue. Parallel cultures were also prepared in duplicate in one milliliter chamber slides (Nunc Rochester, NY) for the analysis of apoptosis using the TUNEL assay following the manufacturer's directions (Roche, Inc., Indianapolis, IN) with some modifications outlined previously [24]. A minimum of 100 cells were analyzed for each sample; experiments were repeated three times for a total of 300 cells for each treatment and dose, respectively for the analysis of apoptosis by the TUNEL assay. An additional positive control, 1.68 Molar DNase (Sigma St. Louis, MO) was used for the analysis of apoptosis. Twenty-four hours after dosing, cells in the chamber slides were fixed in $4 \%$ paraformaldehyde in phosphate buffer (Sigma St. Louis, MO) and stained with DAPI (Millipore Billerica, MA). The resulting stained samples were fluorescently analyzed using a Zeiss Axiophot fluorescent microscope (Carl Zeiss Microimaging Inc. Thornwood, NY).

\section{Mitotic spindle analysis}

BEAS-2B was cultured in 1 milliliter chamber slides as described previously. Dual chambers were prepared for each treatment and each cell type. Three independent experiments were prepared for each cell type and treatment [24]. A minimum of 100 cells of good centrosome and mitotic spindle morphology were analyzed for each sample; experiments were repeated three times for a total of 300 cells for each treatment and dose, respectively. The centrosome integrity as well as the dispersion 
of carbon nanotubes in the cell cultures was evaluated The spindle integrity of the BEAS-2B cells was examined using dual-label immunofluorescence for tubulin and centrin to detect the mitotic spindle and the centrosomes, respectively. Primary rabbit anti-beta tubulin (Abcam, La Jolla, CA, USA) and mouse anti-centrin antibodies (a generous gift from Dr. Jeff Salisbury), and secondary Rhodamine Red goat anti-rabbit IgG and Alexa 488 goat anti-mouse IgG antibodies (Invitrogen, Carlsbad, CA) were used. The mitotic spindle and centrosome morphology were analyzed in the BEAS-2B cells using a laser scanning confocal microscope (LSM 510, Carl Zeiss MicroImaging Inc., Thornwood, NY) as previously described [103]. Briefly, a monopolar or multipolar mitotic spindle was counted as disrupted. The location of MWCNT was determined by differential interference contrast. Because the nanotubes block the light, the nanotubes produce a black image. To determine the association of the MWCNT with the microtubules of the mitotic spindle and the centrosome, serial optical slices was obtained to create a z-stack and permit threedimensional reconstruction using LightWave software [104] by TEM following methods outlined previously [103]. Briefly, cells were fixed in $2 \%$ glutaraldehyde in sodium phosphate buffer, $\mathrm{pH} 7.2$, for $2 \mathrm{~h}$, postfixed in osmium tetroxide, dehydrated through an ethanol series, and embedded in Spurr's resin (Sigma, St Louis, MO). Silver-gold sections were stained in $2 \%$ aqueous uranyl acetate and Reynolds' lead citrate, observed using a JEOL 1200 EX electron microscope and recorded digitally.

\section{Chromosome number by fluorescence in situ hybridization (FISH)}

Due to the necessity of a normal diploid karyotype for the analysis of chromosome number, the SAEC cells were prepared for analysis of the chromosome number. Fluorescence in situ hybridization (FISH) for human chromosomes 1 and 4 was used to determine the chromosome number (Abbott Molecular, Des Plaines, IL) according to the guidelines of the American College of Medical Genetics [105]. Three independent experiments for a total of 300 cells were evaluated for each treatment and dose. A minimum of 100 interphase cells of good FISH morphology were analyzed to determine the number of chromosome 1 and 4. The SAEC cells were photographed using a Zeiss Axiophot microscope and Genetix Cytovision software. Cells with three copies or greater than 4 copies of chromosome 1 or 4 were recorded as a gain for that chromosome. Cells with less than two copies of chromosome 1 or 4 were recorded as a loss of that chromosome. The loss and gain of both chromosomes were added to obtain the errors in chromosome number (aneuploidy).

\section{Colony formation}

Triplicate cultures of SAEC cells were grown in T25 flasks. When the cells were $70 \%$ confluent they were treated with MWCNT. After 24 hours, the cells were trypsinized, counted and plated at 500 cells/well in 6well plates for analysis of colony formation. One month following exposure, the cells were washed with PBS, stained with $10 \%$ crystal violet solution in neutral buffered formalin (Sigma, Saint Louis, MO) and colonies counted.

\section{Cell cycle analysis for DNA content}

BEAS-2B cells were grown in six parallel T25 flasks. A total of 9 independent experiments were performed for the analysis of cell cycle. Twenty-four hours after exposure to $24 \mu \mathrm{g} / \mathrm{cm}^{2}$ MWCNT or to the positive control, $5 \mu \mathrm{M}$ arsenic (Sigma, St Louis MO), the cells were washed twice with PBS and removed from the dishes with $0.25 \%$ trypsin prior to detection of the cell cycle. The cells were stained according to (Invitrogen) manufacturer's instructions. EdU (5-ethynyl-2'-deosyuridine) is a nucleoside analog of thymidine and is incorporated into DNA during active DNA synthesis. Detection is based on a click reaction- a copper catalyzed covalent reaction between an azide and an alkyne. Twenty-four hours after exposure to MWCNT, the cells were washed twice with PBS and incubated with EdU for 2 hours to detect cells in S-phase. Following incubation, the cells were removed from the plate using $0.25 \%$ trypsin. After fixation and Click-iT Saponin permeabilization, $\mathrm{CuSO}_{4}$ was added to the cells to detect the EdU signal. The total amount of DNA was analyzed following incubation with 7AAD (7-aminoactinomycin D) using a LSR II flow cytometer (BD Biosciences Immunocytometry Systems, San Jose, CA). Data were analyzed and plotted using FlowJo v7.2.5 software.

\section{Statistical analysis}

All analyses were performed using SAS/STAT (Version 9.3) for Windows. Chi-square analysis was used to determine statistical significance for the scoring of the mitotic spindle abnormalities and the number of cells with abnormal chromosome number. The number of viable and apoptotic cells were analyzed using analysis of variance (ANOVA). The mean of duplicate samples were used for the analysis. For cell cycle analysis, a mixed model ANOVA was used to compare the proportion of cells in G1, S and G2/M phase across treatment groups. Experimental block was utilized as a random factor. All differences were considered statistically significant at $\mathrm{p}<0.05$. 


\section{Additional file}

Additional file 1: Metal composition of Pristine and Acid-washed MWCNT. Table: The table demonstrates the metal composition of the pristine and 1 hour acid-washed MWCNTs as measured by energy dispersive X-ray spectroscopy (EDX).

\section{Competing interests}

The authors declare that they have no competing interests.

\section{Authors' contributions}

KJS contributed to the study design, writing of the manuscript, conducted experiments and analyzed FISH signals. LMS conceived of and designed the study, analyzed the experimental results and drafted the manuscript. SHR and MLK contributed to the experimental design, acquisition of funding and writing of the manuscript. MLK also analyzed the data for statistical significance. DTL contributed to the study design, conducted the experiments as well as contributed to the analysis of the data. CD acid washed the MWCNT and performed analysis of the material. AFH contributed to the study design and writing of the manuscript and acquisition of funding. JLS was involved in acquisition of funding and writing of the manuscript. DWP contributed to the study design and calculations of the dose for exposure. CZD contributed to the preparation and characterization of the MWCNT and drafting the description of the manuscript. MK performed ICP-MS and drafting of the manuscript. JM, KB MS and JS contributed to writing of the manuscript and materials characterization. LC assisted with MWCNT characterization and photography, writing of the manuscript and preparation of the figures. All authors read and approved the final manuscript.

\section{Acknowledgements}

The authors would like to thank Mike Gipple, Scientific Arts, LLC, Morgantown, WV for his help with three dimensional reconstructions, Kimberly Clough-Thomas for her help with the images and Adrienne McGraw, WVU for her help with scanning electron microscopy imaging. This work was supported by NIOH NORA $9927 Z 8 \mathrm{~V}$ and NSF EPS-1003907.

\section{Disclaimer}

Research findings and conclusions are those of the authors and do not necessarily represent the views of the National Institute for Occupational Safety and Health.

\section{Author details}

${ }^{1}$ National Institute for Occupational Safety and Health, Morgantown, WV 26505, USA. ²Department of Chemical Engineering, Benjamin M. Statler College of Engineering and Mineral Resources, West Virginia University, Morgantown, WV 26505, USA. ${ }^{3}$ Department of Biochemistry, Mayo Clinic, 2001st Street NW, Rochester, MN 55905, USA. ${ }^{4}$ Department of Occupational \& Environmental Health Sciences, West Virginia University, Morgantown, W 26506, USA. ${ }^{5}$ RJ Lee Group Inc, 300 Hockenberg Drive, Monroeville, PA 15146, USA.

Received: 13 June 2013 Accepted: 16 January 2014

Published: 30 January 2014

\section{References}

1. De Volder MF, Tawfick SH, Baughman RH, Hart AJ: Carbon nanotubes: present and future commercial applications. Science 2013, 339:535-539.

2. Liu J, Rinzler AG, Dai HJ, Hafner JH, Bradley RK, Boul PJ, Lu A, Iverson T, Shelimov K, Huffman CB, et al: Fullerene pipes. Science 1998, 280:1253-1256.

3. McAllister K, Sazani P, Adam M, Cho MJ, Rubinstein M, Samulski RJ, DeSimone JM: Polymeric nanogels produced via inverse microemulsion polymerization as potential gene and antisense delivery agents. J Am Chem Soc 2002, 124:15198-15207.

4. Bradley J, Nordan MM, Tassinari O: The Recession's Ripple Effect on Nanotech, Book The Recession's Ripple Effect on Nanotech. Boston, MA: Lux Research, Inc; 2009.

5. Erdely A, Dahm M, Chen BT, Zeidler-Erdely PC, Fernback JE, Birch ME, Evans DE, Kashon ML, Deddens JA, Hulderman T, et al: Carbon nanotube dosimetry: from workplace exposure assessment to inhalation toxicology. Part Fibre Toxicol 2013, 10:53.

6. Han JH, Lee EJ, Lee JH, So KP, Lee YH, Bae GN, Lee SB, Ji JH, Cho MH, Yu IJ: Monitoring multiwalled carbon nanotube exposure in carbon nanotube research facility. Inhal Toxicol 2008, 20:741-749.

7. Maynard AD, Baron PA, Foley M, Shvedova AA, Kisin ER, Castranova V: Exposure to carbon nanotube material: aerosol release during the handling of unrefined single-walled carbon nanotube material. J Toxicol Environ Health A 2004, 67:87-107.

8. Yeganeh B, Kull CM, Hull MS, Marr LC: Characterization of airborne particles during production of carbonaceous nanomaterials. Environ Sci Technol 2008, 42:4600-4606.

9. Donaldson K, Murphy FA, Duffin R, Poland CA: Asbestos, carbon nanotubes and the pleural mesothelium: a review of the hypothesis regarding the role of long fibre retention in the parietal pleura, inflammation and mesothelioma. Part Fibre Toxicol -, 7:5.

10. Oberdorster G: Safety assessment for nanotechnology and nanomedicine: concepts of nanotoxicology. J Intern Med 2010, 267:89-105.

11. Kato T, Totsuka Y, Ishino K, Matsumoto Y, Tada Y, Nakae D, Goto S, Masuda S, Ogo S, Kawanishi M, et al: Genotoxicity of multi-walled carbon nanotubes in both in vitro and in vivo assay systems. Nanotoxicology 2013, 7:452-461.

12. Monteiro-Riviere NA, Nemanich RJ, Inman AO, Wang YY, Riviere JE: Multi-walled carbon nanotube interactions with human epidermal keratinocytes. Toxicol Lett 2005, 155:377-384.

13. Muller J, Decordier I, Hoet PH, Lombaert N, Thomassen L, Huaux F, Lison D, Kirsch-Volders M: Clastogenic and aneugenic effects of multi-wall carbon nanotubes in epithelial cells. Carcinogenesis 2008, 29:427-433.

14. Ponti J, Broggi F, Mariani V, De Marzi L, Colognato R, Marmorato P, Gioria S, Gilliland D, Pascual Garcia C, Meschini S, et al: Morphological transformation induced by multiwall carbon nanotubes on Balb/3 T3 cell model as an in vitro end point of carcinogenic potential. Nanotoxicology 2013, 7:221-233

15. Tavares AM, Louro H, Antunes S, Quarre S, Simar S, De Temmerman PJ, Verleysen E, Mast J, Jensen KA, Norppa H, et al: Genotoxicity evaluation of nanosized titanium dioxide, synthetic amorphous silica and multi-walled carbon nanotubes in human lymphocytes. Toxicol In Vitro 2014, 28:60-69.

16. Di Giorgio ML, Di Bucchianico S, Ragnelli AM, Aimola P, Santucci S, Poma A: Effects of single and multi walled carbon nanotubes on macrophages: cyto and genotoxicity and electron microscopy. Mutat Res 2011, 722:20-31.

17. Li X, Peng Y, Qu X: Carbon nanotubes selective destabilization of duplex and triplex DNA and inducing B-A transition in solution. Nucleic Acids Res 2006, 34:3670-3676.

18. Li X, Peng Y, Ren J, Qu X: Carboxyl-modified single-walled carbon nanotubes selectively induce human telomeric i-motif formation. Proc Natl Acad Sci USA 2006, 103:19658-19663.

19. Sargent $L M$, Hubbs AF, Young SH, Kashon ML, Dinu CZ, Salisbury JL, Benkovic SA, Lowry DT, Murray AR, Kisin ER, et al: Single-walled carbon nanotube-induced mitotic disruption. Mutat Res 2012, 745:28-37.

20. Rodriguez-Fernandez L, Valiente R, Gonzalez J, Villegas JC, Fanarraga ML: Multiwalled carbon nanotubes display microtubule biomimetic properties in vivo, enhancing microtubule assembly and stabilization. ACS Nano 2012, 6:6614-6625.

21. Cortez BA, Machado-Santelli GM: Chrysotile effects on human lung cell carcinoma in culture: 3-D reconstruction and DNA quantification by image analysis. BMC Cancer 2008, 8:181

22. Cortez BD, Quassollo G, Caceres A, Machado-Santelli GM: The fate of chrysotile-induced multipolar mitosis and aneuploid population in cultured lung cancer cells. PLOS One 2011, 6:1860.

23. Ramirez P, Eastmond DA, Laclette JP, Ostrosky-Wegman P: Disruption of microtubule assembly and spindle formation as a mechanism for the induction of aneuploid cells by sodium arsenite and vanadium pentoxide. Mutat Res 1997, 386:291-298.

24. Sargent LM, Shvedova AA, Hubbs AF, Salisbury JL, Benkovic SA, Kashon ML, Lowry DT, Murray AR, Kisin ER, Friend S, et al: Induction of aneuploidy by single-walled carbon nanotubes. Environ Mol Mutagen 2009, 50:708-717.

25. Ehrlich VA, Nersesyan AK, Hoelzi C, Ferk F, Bichler J, Valic E, Schaffer A, Schulte-Hermann $\mathrm{R}$, Fenech $\mathrm{M}$, Wagner $\mathrm{KH}$, Knasmuller S: Inhalative exposure to vanadium pentoxide causes DNA damage in workers: results of a multiple end point study. Environ Health Perspect 2008, 116:1689-1693. 
26. Ress NB, Chou BJ, Renne RA, Dill JA, Miller RA, Roycroft JH, Hailey JR, Haseman JK, Bucher JR: Carcinogenicity of inhaled vanadium pentoxide in F344/N rats and B6C3F1 mice. Toxico/ Sci 2003, 74:287-296.

27. Yegles M, Janson X, Dong HY, Renier A, Jaurand MC: Role of fibre characteristics on cytotoxicity and induction of anaphase/telophase aberrations in rat pleural mesothelial cells in vitro: correlations with in vivo animal findings. Carcinogenesis 1995, 16:2751-2758.

28. Yegles M, Saint-Etienne $L$, Renier A, Janson $X$, Jaurand MC: Induction of metaphase and anaphase/telophase abnormalities by asbestos fibers in rat pleural mesothelial cells in vitro. Am J Respir Cell Mol Biol 1993, 9:186-191.

29. Hubbs A, Castranova V, Chen BT, Frazer DG, McKinney W, Mercer RR, Kashon ML, Battelli LA, Willard P, Porter DW: Pulmonary inflammation, epithelial hyperplasia, and lymph node translocation after multi-walled carbon nanotube inhalation. Washington DC. Toxicol Sci 2011, 120:11.

30. Porter DW, Hubbs AF, Mercer RR, Wu N, Wolfarth MG, Sriram K, Leonard S, Battelli L, Schwegler-Berry D, Friend S, et al: Mouse pulmonary dose- and time course-responses induced by exposure to multi-walled carbon nanotubes. Toxicology 2010, 269:136-147.

31. Shvedova AA, Kisin E, Murray AR, Johnson VJ, Gorelik O, Arepalli S, Hubbs AF, Mercer RR, Keohavong P, Sussman N, et al: Inhalation vs. aspiration of singlewalled carbon nanotubes in C57BL/6 mice: inflammation, fibrosis, oxidative stress, and mutagenesis. Am J Physiol Lung Cell Mol Physiol 2008, 295:L552-L565.

32. Shvedova AA, Kisin ER, Mercer R, Murray AR, Johnson VJ, Potapovich Al, Tyurina YY, Gorelik O, Arepalli S, Schwegler-Berry D, et al: Unusual inflammatory and fibrogenic pulmonary responses to single-walled carbon nanotubes in mice. Am J Physiol Lung Cell Mol Physiol 2005, 289:L698-L708.

33. Porter DW, Hubbs AF, Chen TB, McKinney W, Mercer RR, Wolfarth MG, Battelli L, Wu N, Sriram K, Leonard S, et al: Acute pulmonary dose-responses to inhaled multi-walled carbon nanotubes. Nanotoxicology 2012, 269:136-147.

34. Bauer AK, Dwyer-Nield LD, Hankin JA, Murphy RC, Malkinson AM: The lung tumor promoter, butylated hydroxytoluene (BHT), causes chronic inflammation in promotion-sensitive BALB/CByJ mice but not in promotion-resistant CXB4 mice. Toxicology 2001, 169:1-15.

35. Bauer AK, Dwyer-Nield LD, Keil K, Koski K, Malkinson AM: Butylated hydroxytoluene (BHT) induction of pulmonary inflammation: a role in tumor promotion. Exp Lung Res 2001, 27:197-216.

36. Bauer AK, Rondini EA: REVIEW PAPER: the role of inflammation in mouse pulmonary neoplasia. Vet Pathol 2009, 46:369-390.

37. Hussain SP, Harris CC: Inflammation and cancer: an ancient link with novel potentials. Int J Cancer 2007, 121:2373-2380.

38. Malkinson AM: Role of inflammation in mouse lung tumorigenesis: a review. Exp Lung Res 2005, 31:57-82.

39. Pitot HC: Endogenous carcinogenesis - the role of tumor promotion. Proc Soc Exp Biol Med 1991, 198:661-666.

40. Pitot HC: Multistage carcinogenesis - genetic and epigenetic mechanisms in relation to cancer prevention. Cancer Detect Prev 1993, 17:567-573.

41. Markowitz SB, Levin SM, Miller A, Morabia A: Asbestos. Am J Respir Crit Care Med: Asbestosis, Smoking and Lung Cancer: New Findings from the North American Insulator Cohort; 2013.

42. Naimi Al, Cole SR, Hudgens MG, Brookhart MA, Richardson DB: Assessing the component associations of the healthy worker survivor bias: occupational asbestos exposure and lung cancer mortality. Ann Epidemiol 2013, 23:334-341.

43. Mercer R, Hubbs A, Scabilloni J, Wang L, Battelli L, Schwegler-Berry D, Castranova V, Porter D: Distribution and persistence of pleural penetrations by multi-walled carbon nanotubes. Part Fibre Toxicol 2013, 7:28.

44. Ryman-Rasmussen JP, Cesta MF, Brody AR, Shipley-Phillips JK, Everitt JI, Tewksbury EW, Moss OR, Wong BA, Dodd DE, Andersen ME, Bonner JC: Inhaled carbon nanotubes reach the subpleural tissue in mice. Nat Nanotechnol 2009, 4:747-751

45. Sargent LM, Reynolds SH, Lowry D, Kashon ML, Benkovic SA, Salisbury JL, Hubbs AF, Keane MJ, Mastovich J, Bunker KL, et al: Genotoxicity of multi-walled carbon nanotubes at occupationally relevant doses. Proc Am Assoc Cancer Res 2012, 53:1320. Abstract \#5464.

46. Stone KC, Mercer RR, Gehr P, Stockstill B, Crapo JD: Allometric relationships of cell numbers and size in the mammalian lung. Am J Respir Cell Mol Biol 1992, 6:235-243.

47. Hubbs A, Greskevitch M, Kuempel E, Suarez F, Toraason M: Abrasive blasting agents: designing studies to evaluate relative risk. J Toxicol Environ Health A 2005, 68:999-1016.
48. 29 CFR-Occupational Safety and Health Regulations (OSHA Standards). https://www.osha.gov/pls/oshaweb/owadisp.show_document? p_table $=$ standards\&p_id $=9992$.

49. Health NIOSH: Current Intelligence Bulletin 65: Occupational Exposure to Carbon Nanotubes and Nanofibers; 2013.

50. Lee JH, Lee SB, Bae GN, Jeon KS, Yoon JU, Ji JH, Sung JH, Lee BG, Lee JH, Yang JS, et al: Exposure assessment of carbon nanotube manufacturing workplaces. Inhal Toxicol 2010, 22:369-381.

51. Maynard AD, Aitken RJ: Assessing exposure to airborne nanomaterials: current abilities and future requirements. Nanotoxicology 2007, 1:26-41.

52. Methner M, Hodson L, Dames A, Geraci C: Nanoparticle Emission Assessment Technique (NEAT) for the identification and measurement of potential inhalation exposure to engineered nanomaterials-Part B: Results from 12 field studies. J Occup Environ Hyg 2010, 7:163-176.

53. British Standards Institution: Nanoparticle - Vocabulary, Book Nanoparticle Vocabulary. Grimsby, UK: Castle PRess; 2011.

54. Porter AE, Gass M, Bendall JS, Muller K, Goode A, Skepper JN, Midgley PA, Welland M: Uptake of noncytotoxic acid-treated single-walled carbon nanotubes into the cytoplasm of human macrophage cells. ACS Nano 2009, 3:1485-1492.

55. Marcolongo G, Ruaro G, Gobbo M, Meneghetti M: Amino acid functionalization of double-wall carbon nanotubes studied by Raman spectroscopy. Chem Commun (Camb) 2007, 5:4925-4927.

56. Datsyuk V, Kalyva M, Papagelis K, Parthenios J, Tasis D, Siokou A, Kallitsis I, Galiotis C: Chemical oxidation of multiwalled carbon nanotubes. Carbon 2008, 46:833-840.

57. Underhill DM, Goodridge HS: Information processing during phagocytosis. Nat Rev Immunol 2012, 12:492-502.

58. Dinu CZ, Zhu G, Bale SS, Anand G, Reeder PJ, Sanford K, Whited G, Kane RS, Dordick JS: Enzyme-based nanoscale composites for Use as active decontamination surfaces. Adv Funct Mater 2010, 20:392-398.

59. Wiktor AE, Van Dyke DL, Stupca PJ, Ketterling RP, Thorland EC, Shearer BM, Fink SR, Stockero KJ, Majorowicz JR, Dewald GW: Preclinical validation of fluorescence in situ hybridization assays for clinical practice. Genet Med 2006, 8:16-23

60. Yurov YB, lourov IY, Monakhov W, Soloviev IV, Vostrikov VM, Vorsanova SG: The variation of aneuploidy frequency in the developing and adult human brain revealed by an interphase FISH study. J Histochem Cytochem 2005, 53:385-390.

61. lijima S: Helical microtubules of graphitic carbon. Nature 1991, 354:56-58

62. Chiu JC, Chang CM, Hsieh BZ, Lin SC, Yeh CY, Lin GR, Lee CK, Lin JJ, Cheng WH: Pulse shortening mode-locked fiber laser by thickness and concentration product of carbon nanotube based saturable absorber. Opt Express 2011, 19:4036-4041.

63. Yang WR, Thordarson P, Gooding JJ, Ringer SP, Braet F: Carbon nanotubes for biological and biomedical applications. Nanotechnology 2007, 18:412001.

64. Bonner JC, Silva RM, Taylor A, Brown JM, Hilderbrand SC, Castranova V, Porter DW, Elder A, Oberdörster G, Harkema JR, Bramble LA, Kavanagh TJ, Botta D, Nel A, Pinkerton KE: Interlaboratory Evaluation of Rodent Pulmonary Responses to Engineered Nanomaterials: The NIEHS Nano GO Consortium. Environ Health Perspect 2013, 121:676-682.

65. Oberdorster G, Stone V, Donaldson K: Toxicology of nanoparticles: a historical perspective. Nanotoxicology 2007, 1:2-25.

66. Pitot HC, Campbell HA, Maronpot R, Bawa N, Rizvi TA, Xu YH, Sargent L, Dragan Y, Pyron M: Critical parameters in the quantitation of the stages of initiation, promotion, and progression in one model of hepatocarcinogenesis in the rat. Toxicol Pathol 1989, 17:594-611.

67. D'Assoro AB, Busby R, Suino K, Delva E, Almodovar-Mercado GJ, Johnson H, Folk C, Farrugia DJ, Vasile V, Stivala F, Salisbury JL: Genotoxic stress leads to centrosome amplification in breast cancer cell lines that have an inactive G1/S cell cycle checkpoint. Oncogene 2004, 23:4068-4075.

68. Lingle WL, Lukasiewicz K, Salisbury JL: Deregulation of the centrosome cycle and the origin of chromosomal instability in cancer. Adv Exp Med Biol 2005, 570:393-421.

69. Lingle WL, Salisbury JL: Methods for the analysis of centrosome reproduction in cancer cells. Methods Cell Biol 2001, 67:325-336.

70. Dinu CZ, Bale SS, Zhu GY, Dordick JS: Tubulin encapsulation of carbon nanotubes into functional hybrid assemblies. Small 2009, 5:310-315.

71. Canman JC, Cameron LA, Maddox PS, Straight A, Tirnauer JS, Mitchison TJ, Fang GW, Kapoor TM, Salmon ED: Determining the position of the cell division plane. Nature 2003, 424:1074-1078. 
72. Chial HJ, Giddings TH, Siewert EA, Hoyt MA, Winey M: Altered dosage of the Saccharomyces cerevisiae spindle pole body duplication gene, NDC1, leads to aneuploidy and polyploidy. Proc Natl Acad Sci USA 1999, 96:10200-10205.

73. Hong KU, Park YS, Seong YS, Kang DM, Bae CD, Park J: Functional importance of the anaphase-promoting complex-Cdh1-mediated degradation of TMAP/CKAP2 in regulation of spindle function and cytokinesis. Mol Cell Biol 2007, 27:3667-3681.

74. Asakura M, Sasaki T, Sugiyama T, Takaya M, Koda S, Nagano K, Arito H, Fukushima S: Genotoxicity and cytotoxicity of multi-wall carbon nanotubes in cultured Chinese hamster lung cells in comparison with chrysotile A fibers. J Occup Health 2010, 52:155-166.

75. Mangum JB, Turpin EA, Antao-Menezes A, Cesta MF, Bermudez E, Bonner JC: Single-walled carbon nanotube (SWCNT)-induced interstitial fibrosis in the lungs of rats is associated with increased levels of PDGF mRNA and the formation of unique intercellular carbon structures that bridge alveolar macrophages in situ. Part Fibre Toxicol 2006, 3:15.

76. Mardin BR, Schiebel E: Breaking the ties that bind: new advances in centrosome biology. J Cell Biol 2012, 197:11-18.

77. Seitz A, Kojima H, Oiwa K, Mandelkow EM, Song YH, Mandelkow E: Single-molecule investigation of the interference between kinesin tau and MAP2c. EMBO J 2002, 21:4896-4905.

78. Nieznanska H, Dudek E, Zajkowski T, Szczesna E, Kasprzak AA, Nieznanski K: Prion protein impairs kinesin-driven transport. Biochem Biophys Res Commun 2012, 425:788-793.

79. Seitz A, Kojima H, Oiwa K, Mandelkow EM, Song YH, Mandelkow E: Tau and MAP2 inhibit attachment of kinesin: single-molecule assay of motility in the presence of MAPs. Biophys J 2002, 82:63a-63a.

80. Thies E, Biernat J, Mandelkow EM: MARK/Par1 kinase is a regulator of microtubule-dependent transport in axons by phosphorylating tau protein. Neurobiol Aging 2004, 25:S427-S427.

81. Lengauer C, Kinzler KW, Vogelstein B: Genetic instabilities in human cancers. Nature 1998, 396:643-649.

82. Rangaswami H, Bulbule A, Kundu GC: Osteopontin: role in cell signaling and cancer progression. Trends Cell Biol 2006, 16:79-87.

83. Rikova K, Guo A, Zeng Q, Possemato A, Yu J, Haack H, Nardone J, Lee K, Reeves C, Li Y, et al: Global survey of phosphotyrosine signaling identifies oncogenic kinases in lung cancer. Cell 2007, 131:1190-1203.

84. Pampaloni F, Florin EL: Microtubule architecture: inspiration for novel carbon nanotube-based biomimetic materials. Trends Biotechnol 2008, 26:302-310.

85. Shimamoto Y, Maeda YT, Ishiwata S, Libchaber AJ, Kapoor TM: Insights into the micromechanical properties of the metaphase spindle. Cell 2011, 145:1062-1074.

86. Donaldson K, Aitken R, Tran L, Stone V, Duffin R, Forrest G, Alexander A: Carbon nanotubes: a review of their properties in relation to pulmonary toxicology and workplace safety. Toxicol Sci 2006, 92:5-22.

87. Donaldson K, Stone V, Seaton A, Tran L, Aitken R, Poland C: Re: Induction of mesothelioma in p53 mouse by intraperitoneal application of multi-wall carbon nanotube. J Toxicol Sci 2008, 33:385-388.

88. Mercer RR, Hubbs AF, Scabilloni JF, Wang L, Battelli LA, Friend S, Castranova V, Porter DW: Pulmonary fibrotic response to aspiration of multi-walled carbon nanotubes. Part Fibre Toxicol 2011, 8:21.

89. Mercer RR, Scabilloni JF, Hubbs AF, Battelli LA, McKinney W, Friend S, Wolfarth MG, Andrew M, Castranova V, Porter DW: Distribution and fibrotic response following inhalation exposure to multi-walled carbon nanotubes. Part Fibre Toxicol 2013, 10

90. Frost $\mathrm{G}$, Darnton $\mathrm{A}$, Harding $\mathrm{AH}$ : The effect of smoking on the risk of lung cancer mortality for asbestos workers in Great Britain (1971-2005). Ann Occup Hyg 2011, 55:239-247.

91. Frost $G$, Harding AH, Darnton A, McElvenny D, Morgan D: Occupational exposure to asbestos and mortality among asbestos removal workers: a Poisson regression analysis. Br J Cancer 2008, 99:822-829.

92. Kane AB: Animal models of malignant mesothelioma. Inhal Toxicol 2006, 18:1001-1004

93. Metintas S, Metintas M, Ak G, Kalyoncu C: Environmental asbestos exposure in rural Turkey and risk of lung cancer. Int J Environ Health Res 2012, 22:468-479.

94. Takagi A, Hirose A, Nishimura T, Fukumori N, Ogata A, Ohashi N, Kitajima S, Kanno J: Induction of mesothelioma in p53+/- mouse by intraperitoneal application of multi-wall carbon nanotube. J Toxicol Sci 2008, 33:105-116.
95. Takagi A, Hirose A, Futakuchi M, Tsuda H, Kanno J: Dose-dependent mesothelioma induction by intraperitoneal administration of multi-wall carbon nanotubes in p53 heterozygous mice. Cancer Sci 2012, 103:1440-1444.

96. Nagai H, Okazaki Y, Chew SH, Misawa N, Yamashita Y, Akatsuka S, Ishihara T, Yamashita K, Yoshikawa Y, Yasui H, et al: Diameter and rigidity of multiwalled carbon nanotubes are critical factors in mesothelial injury and carcinogenesis. Proc Natl Acad Sci USA 2011, 108:E1330-E1338.

97. Sargent LM, Porter DW, LM S, AF H, Lowry DT LB, KJ S, ML K, RR M, AK B, et al: Promotion of lung adenocarcinoma following inhalation exposure to multi-walled carbon nanotubes. Part Fibre Toxicol. in press.

98. Devereux TR, Anderson MW, Belinsky SA: Role of Ras protooncogene activation in the formation of spontaneous and nitrosamine-induced lung-tumors in the resistant C3h mouse. Carcinogenesis 1991, 12:299-303.

99. Malkinson AM: The genetic-basis of susceptibility to lung-tumors in mice. Toxicology 1989, 54:241-271.

100. Chen CY, Ge CC, Lao F, Li W, Li YF, Qiu Y, Mao XY, Li B, Chai ZF, Zhao YL: Quantitative analysis of metal impurities in carbon nanotubes: efficacy of different pretreatment protocols for ICPMS spectroscopy. Anal Chem 2008, 80:9426-9434.

101. Food and Drug Administration: Guidance for industry: assessing the effects of significant manufacturing process changes, including emerging technologies, on teh safety and regulatory status of food ingredients and food contact substances, including food ingredients that are color additives - draft guidance. In Book Guidance for Industry: Assessing the Effects of Significant Manufacturing Process Changes, Including Emerging Technologies, on teh Safety and Regulatory Status of Food Ingredients and Food Contact SUbstances, Including Food Ingredients that are Color Additives - Draft Guidance. Rockville, MD: Food and Drug Administration; 2012.

102. Oxford Dictionaries Online. http://oxforddictionaries.com/.

103. Salisbury JL, D'Assoro AB, Lingle WL: Centrosome amplification and the origin of chromosomal instability in breast cancer. J Mammary Gland Biol Neoplasia 2004, 9:275-283.

104. Haas A, Fischer MS: Three-dimensional reconstruction of histological sections using modern product-design software. Anat Rec 1997, 249:510-516.

105. ACMG: Standards and guidelines for clinical genetics laboratories, in: documentation of FISH results. Bethesda, MD: American College of Medical Genetics; 2006.

doi:10.1186/1743-8977-11-6

Cite this article as: Siegrist et al:: Genotoxicity of multi-walled carbon nanotubes at occupationally relevant doses. Particle and Fibre Toxicology 2014 11:6.

\section{Submit your next manuscript to BioMed Central and take full advantage of:}

- Convenient online submission

- Thorough peer review

- No space constraints or color figure charges

- Immediate publication on acceptance

- Inclusion in PubMed, CAS, Scopus and Google Scholar

- Research which is freely available for redistribution 